\title{
THREATS AND RISKS GENERATED BY ILLEGAL MIGRATION FLOWS AND THEIR CONTROL
}

\author{
Lucian Ioan TARNU \\ lucian_tarnu@yahoo.com
}

\section{Police InSPECTORATE OF SibiU COUNTY AND THE "LUCIAN BLAGA" UNIVERSITY IN SibIU}

\begin{abstract}
Migration has existed since the beginning of mankind. The phenomenon has not been ceased in time, but it has changed and acquired new forms. Migration processes are conducted simultaneously and they are increasing in many countries. One of the long term results of this development could be the emergence of multicultural societies, tending towards new concepts of citizenship or national state. Most of the developed countries have become diversified and multiethnic societies, and those who have not reached this level yet, have turned decisively in this direction.

The social consequences of migration are as important as its influence on the economy. The regulation of the migration processes supposes the application of legal, administrative and socio-economic measures that are aimed to stimulate or limit the migration of population in or from the country, to ensure the respect of the migrants' rights, to fight against both the illegal migration and illicit trafficking in human beings.
\end{abstract}

\section{Keywords}

Migration, population, threats, risks, crime, organized crime

\section{Overview on Threats of Illegal Migration}

The social, economic and political developments that have occurred in recent decades and that are running globally, have created the premises for significant changes in migration, requiring to pay special attention to these problems which are addressed more frequently within political dialogue and international cooperation.

The specialized international organizations find that, at present, the extent of this process is not enough known and there are no accurate statistics that reflect the proportions of global migration and allow its fair assessment to develop appropriate policies.
The manifestation of crime as a global phenomenon and the danger represented by crime, in general and, in particular, by the organized crime, represents an ongoing concern of the designated bodies to fight to prevent and combat this flagellum of the modern world.

Regulating a complex social problem, whose ways of expression, social consequences and ways of solving represents an interest for both institutional factors of social control and public opinion. Crime is today an extremely serious and dangerous factor turning into organized crime, generating a series of negative and destructive consequences on the structure and stability 
of social organizations and institutions and causing demoralizing conditions and insecurity of individuals and groups of individuals.

The worldwide crime assessment highlights a number of trends in the evolution of human society. These trends cause threats from illegal migration. Among them, there are highlighted, in particular, those relating to demographic, economic inequalities and cultural changes.

The analysis of these strategic trends leads to the following:

a) the demographic evolutions will influence their action in providing security in urban centers that will register a great development. The population migration from both developing and underdeveloped countries to the neighbor countries or developed ones will increase (analyses carried out in these areas show that the world population will reach 9.3 billion people by 2050, and a number of 49 countries among the underdeveloped will triple its population, from 668 million to 8 billion; the urban population will increase from 2.8 to 3.9 billion by 2015 , of which nearly $1 / 3$ will be in the underdeveloped or developing country);

b) the ethnic differences, extreme nationalism, or religious new fundamentalism or radical religion beliefs generate the crises and tensions at national or even international level (there may occur other networks like Al Qaeda); the development and perpetuation of such tensions and crises make the population want to find a security space and, consequently, and to migrate to neighbor or remote countries or even to another continent;

c) the gap concerning the living standards between rich and poor countries will deepen, which will lead to an increase of tension among people and it will also create areas with a population vulnerable to the involvement in criminal activities (the statistics reveals that in the richest countries of the world the consumption represents $86 \%$ of total private consumption).

According to the data of the tests of this year, the illegal migration in the next period will be maintained at high levels and may be larger than in the previous years.

In general, the countries of origin will be among the countries with a weak economy and/or among those who, because of political problems or local conflicts, will generate emigration. Many citizens of these countries will consider that emigration is the only way they can assert their identity and which can lead to their economic, political, social or cultural achievement. These issues will continue to fuel the market managed by criminal organizations dealing with illegal immigration. Although the scale of the phenomenon is not fully known, however the Organization for Cooperation and Economic Development (OCED) estimated the number of illegal immigrants arriving annually in the countries of the European Union, at 500,000, of which $90 \%$ penetrates the borders using criminal organizations.

In general, the risk factors generating illegal immigration, on short and medium term, will be the same. The destination targets pursued by immigrants will still be the European Union, North America and Australia.

The migrants' countries of origin are mainly those located in Asia, and the organizations with the highest degree of danger in the area of illegal immigration will remain in these countries. The countries of the Eastern Europe and Central Asia will be transit or waiting areas for the right time to continue the illegal journey to the country of final destination [2].

\section{The Risks of Migration Phenomenon}

The migration flows have different characteristics, depending on: the conditions that cause their occurrence, their scale, the way that the destination state is capable to manage the migration phenomenon and the migrants' profile. The experience in the field shows that any large-scale migration flow consists in two migration sides: legal and illegal. When referring to illegal migration, we find that it can be accidental or organized.

In general, the accidental illegal migration is easier to be controlled, because 
the migrants do not have the "protection" of criminal organizations and they do not have sufficient knowledge to hide illicit activities and, consequently, they are more easily to be traced by the law enforcement. In such conditions, the danger posed by the infiltration of illegal immigrants among some communities is much lower.

Another aspect is the fact that the accidental migration does not have the frequency characteristics of the organized migration (the migration flows are not permanent) and, thus, there will not be continuous illegal immigration flow into the destination country.

On the contrary, by its effects altering both the social life, in general, and the public order, in particular, the illegal organized migration has a high danger degree. This is pointed out by both the strategic risks of such migration and the impact manifested on the involved countries (of origin, transit and destination).

Once getting instituted a criminal organization that has as objective the smuggling with migrants on the territory of two or more states, it will develop rapidly and cause effects on the stability and the future of those countries.

The main strategic risks arising from migration flows are:

\section{markets}

$\checkmark$ Imbalance of the existing labor

The massive immigration (legal or illegal) of people of working age from the home countries produces substantial changes in the population structure, which generates imbalances in the domestic labor market and has consequences on the economic development.

A key element for the transit countries is the duration of the immigrants' stay on their territory during the journey to the destination countries.

In this respect, many examples point out that many immigrants waiting for the right time to enter the territory or the target country. This waiting can last from weeks and months to several years. Meanwhile, they try to find a temporary job to earn their living and / or continue their journey.

Due to the position they have (in most cases, as illegal immigrant), the work place found on the labor market is illegal and it does not belong to the underground economy.

The smuggling with migrants permanently fuels the existing "black" labor market in the destination country [3].

Thus, placing new illegal migrants on the market creates an unfair competition between older immigrants and those newly arrived. That is a competition which, by increasing the number of offers on the market, is in the advantage of the "employer".

In this way, he can set the price and conditions of employment at will. On the other hand, it should be noted that this situation could trigger violent clashes between immigrants, by which the competitors are put aside from the market. Sometimes, the object of activity of the criminal organizations consists in the control of these forms of human exploitation that are extremely beneficial generating a substantial profit every day.

A special interest in introducing new immigrants onto the black labor market can be shown by the organization itself that deals with trafficking migrants, because some of the immigrants who benefited from the services provided by the network must pay their "debts" with money earned after their arrival in the destination country.

\section{$\checkmark$ Development and diversification of the organized crime}

The cross-border organized crime does not take place in an isolated way. Once created, the networks dealing with smuggling with migrants will diversify rapidly and cooperate with the criminal organizations already existing in other crime areas such as the illegal traffic of persons, drugs, luxury stolen cars, weapons and even terrorism.

The cooperation between these organizations has advantages for both sides because each side can benefit from the "specialized" services provided by business partner. 
$\checkmark$ Economic imbalance caused by the growth of money laundering activities derived from the smuggling with migrants

Because the activity of the smuggling with migrants is financially very profitable due to the so-called purpose of "black labor", it determines the rapid emergence of sophisticated forms of money laundering, within or outside that country, which leads to undermining the financial and commercial market conditions and cause the economic imbalance.

\section{$\checkmark$ Demographic imbalance}

The current challenges facing the direction of studying the emergence and evolution of demographic imbalances are generated by the existence of dangers producing tensions or even crisis situations with serious consequences on the social order, when there are favorable conditions and tensions get worse.

An item with particular influences on the demographic trends is represented by the population migration, and, especially the illegal migration. Thus, the widely practiced illegal migration - especially the regular immigration flows controlled by criminal organizations - can lead to the imbalance of micro or macro population. On the one hand, it is about the number of people who emigrate from a particular country of origin, and, on the other hand, it is about the number of immigrants of a certain ethnic group or nationality who emigrate to a region or a particular labor market in the destination country.

A short time massive influx of immigrants leads to an increase of population which generates an increased consumption and creates crisis. The authorities are being unable to maintain living conditions existing before (proper supply markets with largescale consumption, providing housing, services, rising unemployment, etc.), which will generate hostile reactions from the local population (xenophobic, ultranationalist and racial manifestations).

The intensification of such tensions could lead to violent reactions with particularly serious consequences in terms of public order.

\section{$\checkmark$ Increased corruption among public officials}

The smuggling with migrants goes hand in hand with corruption.

The numerous stages of smuggling create endless corruption "opportunities" among public officials from different structures of the state authorities. Thus, the money periodically paid by criminal organizations to certain public officials is a sure way to undermine the efforts of the entire system of law enforcement in the fight against illegal migration.

The corruption and smuggling with migrants have destructive effects that jeopardize the efficiency of the entire law enforcement system and represent a threat to civil society's trust in the system.

\section{$\checkmark$ Corruption of politicians, intercession and buying influence}

Similarly, the profit obtained by smugglers from criminal activities allow them to intercede and corrupt political system in their favor.

Another aspect might be the possibility of corrupting politicians, blackmailing those who use the facilities of the system created by criminal organizations.

\section{$\checkmark$ Imbalance of economic investment of foreign or national companies in the respective country}

The destructive effects of illegal migration can occur cumulatively. For example, in the countries where the smuggling with migrants led to specific activities of money laundering and corruption in the public sector, the confidence in the economic system of the involved country will decrease and the international big companies will reduce their volume of investments.

The migration phenomenon, besides its undeniable benefits, generates a series of dangers which, if not anticipated, studied and finally taken countermeasures, may jeopardize the public order and even the national security of a state. 
In Romania, in the last 25 years, the immigrants, particularly those from Arab countries, committed economic crimes, such as smuggling, money laundering and tax evasion.

Due to the tendencies of isolation of immigrants in certain areas, there are often conflicts between local people and immigrants.

From the analysis made by the Ministry of Domestic Affairs, it results a certain specialization by type of crime of immigrants according to their country of origin, namely: the Chinese - the removal of currency from the country, illegal migration; the Iraqis - illegal migration; the Turks illegal migration, removing the currency from the country, drug intercession, poaching; the Bulgarians - illegal migration, smuggling, poaching; the Ukrainians illegal migration, prostitution, weapons and ammunition intercession; the Russians illegal migration, car, weapons and ammunition intercession, prostitution; the Italians - car intercession, weapons and ammunition, guide prostitution; the Serbs guide for illegal migration and prostitution, car intercession; the Iranians - illegal migration, drug intercession; the Moldavians - illegal migration, prostitution, cigarette smuggling, smuggling of goods, drug intercession; the Colombians - illegal migration; the Syrians - Illegal migration, removing the currency from the country; the Poles - drug intercession; the Hungarians smuggling (particularly gasoline), illegal persons intercession.

The risks to national security include: cross-border crime, forms of organized crime and terrorism.

Regarding the terrorist acts, Romania has some vulnerability. Thus, in the light of the sources of specific security of the XXIst century, the migration of population is a result of classic vectors, excessive impoverishment, inter-ethnic and interconfessional conflicts, political instability, human rights and minorities abuses, major environmental accidents, changes in geo - climatic area and emerging factors (export of surplus population and religious fundamentalism, import demographic), transnational organized crime and international terrorism.

All these occur due to the increased uncontrolled person intercession, in addition to the fatal consequences of: population explosion ("The Population Bomb"), the insufficient water resources, the major food crisis ("poverty bomb"), the nuclear weapons race practiced by the great powers.

Associating the population migration phenomenon with the international terrorism can be done by analyzing the causes and the future interference on the security system of states.

There is more striking the tendency to use mass expulsion, as a war weapon and as a means to create homogenous societies, from the cultural or ethnic perspective (Syria, ex-Soviet space, Rwanda, Burundi, Liberia, Somalia, Ethiopia, the territory of the former Federal Republic of Yugoslavia).

The massive flows of population refugees and forcefully deported - are increasingly used both in the pre-crisis, and, especially, in the post-crisis period as a direct or concealed reason to support territorial or self-determination claims (Syria, Libya, parts of the former Federal Republic Yugoslavia, the former Soviet Union, Chechnya, Nagorno-Karabakh, Transnistria, Gaza Strip, Cisiordania).

In general, the refugee population, deported by force or expelled, is an unhappy population, which determined by its critical condition, can be easily recruited by terrorist organizations in order to be used in specific operations.

It results that, in the future, the terrorist phenomenon can benefit from a "massive import" of terrorists from different parts of the world.

A category of migratory population, which could widen the terrorist organizations, can be considered the offenders and criminals who, due to the fact that they are given the prosecution in their countries, seek 
refuge in other countries and they are recruited by terrorists.

The increasing influences of the international Islamic circles on the activities developed in Romania and in the area, through the branches of the extremist terrorist and fundamentalist Islamic organizations, and the operational dynamic in this problematic is constantly influenced by international events in areas of potential risk (Balkans, Middle East, Asia).

The evolution of the terrorist phenomenon involves potential new risks and threats to Romania, especially since the favoring additional factors are associated with internal vulnerabilities that could facilitate the organization and the commitment of some terrorist acts against domestic or foreign targets on the national territory. These acts have been previously identified and reported by state institution that are specific to the geopolitical position of Romania determined by:

- the location in the proximity of the conflict area and at the junction of favorite routes of migration flows (Ukraine, Moldova);

- the status of NATO membership, that is an organization that has assumed a key role in preventing and combating terrorism;

- the firm and direct involvement of the Romanian state in the international campaign against terrorism;

- the special relationships between Romania and the states targeted by terrorist activities;

- the exacerbation of the religious and confessional differences, the development of: some nuclei that are of anarchic guidance, radical contesting and extremist-terrorist; the tendencies to become regional autonomous entities in the space near Romania - with the possibility of degenerating into violent actions, with the participation of large masses of people;

- the possibility of proliferation and uncontrolled dissemination of both technologies and equipment that are needed to process dangerous chemicals, strategic products and those that undergo the control of the final destination;
- the homogenization of the interests concerning the transactions with military equipment, weapons and ammunition, the intensification of the operations of brokerage and commercial transfers without physically touching the Romanian territory, entails risks and major vulnerabilities with connotations in compliance with international treaties and agreements on non-proliferation (the involvement of domestic operators in the field in transactions with companies from Ukraine, Bulgaria, with high risk, aiming to change the final destination to sensitive areas);

- the development, the strengthening and the specialization of the organized crime branches, their internationalization by reaching elements of different nationalities and the inclusion of our country's territory into the transnational circuit in the area of clandestine migration, illegal drugs intercession and persons, weapons, explosives, toxic substances, radioactive and counterfeit banknotes;

- the extension of the economic and financial serious crime, represented by corruption and money laundering, in the countries of this geographical region where Romania is located;

- the increasing interest shown by some foreigners who come mainly from areas of military conflict or countries under international embargo, who want to obtain - through illegal financial maneuvers - the majority stake in some companies that produce and use strategic chemicals in order to escape the system legal in the production, use and marketing materials and strategic technologies and to export them directly or through intermediaries to these areas or countries being under embargo;

- the Romania's location at the crossroads of several areas of geo-political and geo-strategic interest.

The analysis on the mechanisms of genesis, affirmation and proliferation of terrorism at international level highlights that, in the future, the terrorist phenomenon will have an unexpected development. 
As far as the ethnic and religious differences are concerned, it is notable how the geo - political climate that is specific to the process of political - military and economic reconfiguration, marked by the radical and continuous balance of power, ensured the transformation of the ethnoreligious issues into an instrument mainly used within the power relationships, especially within the ones having an asymmetric base status.

This process was accompanied by the reactivation and exacerbation of tensions also reflected in the dynamics of terrorism. It may also be taken into consideration the emphasizing of the interferences between terrorism and some segments of organized crime.

Thus, the internationalization of some conflict situations has created favorable conditions for the manifestation of terrorism, and the disappearance of its traditional sponsors has made that the terrorist organizations turn increasingly to specific organized crime activities as main source of funding.

The convergence between terrorism and organized crime is carried out by either involving directly the terrorist networks in actions associated with organized crime (such as: drug intercession, smuggling with weapons, ammunition, explosives, toxic or radioactive substances, all kinds of activities specific to the underground economy, illegal migration) in order to financially support their activities, or by complex actions shared by large structures of terrorist organizations and shady world, determined by circumstance, momentary or future interests, which are meant to facilitate the achievement of the goals of each side.

Following the events of the $11^{\text {th }}$ of September 2001, the NATO member states, and also those that signed the international agreements on transport security, implemented new security measures for the prevention of possible terrorist actions directed towards strategic or economic targets inside harbors.
Accordingly, there was elaborated a program of security of harbors, that is generically called ISPS - the International Code of Security of Ship and Harbors Facility.

Since July 2004, Romania has taken over the ISPS code and started its implementation in the Constanta harbor.

The first step was that of creating a new safety device in Constanta harbor, so that all the harbor operators that have transport facilities in Constanta harbor were obliged by the harbor administration to surround the work areas in the zone that connects the land and the ships moored in the operation berths. All the activity of these berths will be under video surveillance, and the security is ensured by specially trained staff.

Once joining the European Union on the $1^{\text {st }}$ of January 2007, Romania has assumed the role of the European Union's eastern border, in this respect, being well known that, globally, at least from both a demographic perspective, and the one of the difficulties in economic terms, Asia is considered the main migration reservoir of the XXIst century. We are bound to this continent by a green border, which is relatively easily crossed, while the routes of legal/illegal migration, already formed being sufficiently flexible and able to adjust to cyclical changes.

The migration flows do not contain but only in a small way a stable and predictable part. By definition, they manifest a greater sensitivity to the changes of the political, economic, geo-strategic circumstances, at local, regional and global level, especially in the aspect that concerns the refugees and asylum seekers. In the current conditions of globalization, immigration, migration, in general, can't be treated or explained as isolated phenomena as they increase regionally and globally.

After joining the EU, the dynamics and immigration in Romania do not depend only on internal factors such as: the national regime being applicable on migration, the state policy in the field, the development of Romanian economy and society as a whole, etc. An important role turns to external factors. 


\section{Conclusions}

The immigration in Romania could be appreciated only if we take into consideration the regional migratory phenomena, at the level of the European Union, of Europe on the whole, and even at international level.

Even if Romania does not absorb but $1 \%$ of the total number of immigrants arriving annually in the European Union, it may be forced to cope with a large influx of people bigger than the one that has occurred so far.

In addition, if, until now, the main component of immigration highlighted was the repatriation, it is to be expected that, after joining the EU, this feature may be taken over by another type of immigration (asylum seekers, refugees, illegal migration).

In the current circumstances, Romania will have to implement a complex system of immigration management, assuring, partly or wholly, from its own funds, the means of subsistence and accommodation, social services and economic integration.

Confronted to this phenomenon which threatens to become uncontrollable, it becomes increasingly obvious the need of improving the efforts of all countries to reduce and eradicate the factors which contribute to the proliferation of clandestine migration.

\section{References}

1. Massey, Doug S. et al. "Theories of International Migration: A Review and Appraisal", Population and Development Review, vol. 19, no. 3, (1993): 431-466.

2. Data are provided by the National Institute of Statistics. www.insse.ro

3. Ibidem.

\section{Bibliography}

Aelenei Victor, The Law of State Border, volume I, Bucharest: Pro Universitaria Publishing House, 2006.

Albu Alexandru D., International Migration of Work Force, Bucharest: Science and Encyclopedic Publishing House, 1976.

Călinoiu Constanţa, and Victor Duculescu, European Constitutional Law, Bucharest: Lumina Lex Publishing House, 2008.

Diaconu Nicoleta, Judicial System of the European Union, Bucharest: Sylvi Publishing House, 2004.

Duculescu, Victor, Judicial Protection of Human Rights: Internal and International Means, New, revised and amended edition, Bucharest: Lumina Lex Publishing House, 2007.

Gover Jack and Redmond John, Extention of the European Union. Perspectives, Club Europa Publishing House, 2001.

Muraru Ioan, Constantinescu Mihai, Tănăsescu Simina, Enache Marian and Iancu, Gheorghe, Interpretation of the Constitution. Doctrine and Practice, Bucharest: Lumina Lex Publishing House, 2002.

Popescu Ilie, Rădulescu Nicolae and Nicolae Popescu, International Terrorism - Flagellum of the Contemporary World, Bucharest: Ministry of Domestic Affairs, 2003.

Preti Luigi, Immigration in Europe, Bucharest Technical Publishing House, 1993.

Rădulescu Mugurel - Europe in Movement, Bucharest: Tritonic Publishing House, 2005.

Stoica Camelia, Free Movement of Persons in the European Union, Bucharest Oscar Print Publishing House, 2001. 
Tarnu Lucian, Free Movement of Persons in the Conditions of Romania Joining the European Union, Sibiu: TehnoMedia Publishing House, 2008.

Howard Adelman, „Refugee or Asylum Seeker: Philosophical Perspective”, The Journal of Studies on Refugees, 1998.

Mansoor Ali and Bryce Quillin, Migration and remittances. Eastern Europe and Former Soviet Union, Studies on Immigration, Center for Immigration Studies, 2007.

Morawska Eva, "Structuring Migration: The Case of Polish Income-Seeking Travelers to the West", Theory and Society, 2001.

Llee H.. Internal and International Migration: Chinese Perspectives, ed.1999, Londres,

Curson Piore and Michael J. - Birds of Passage: Immigrant Labor Industrial Societies, New York: Cambridge University Press, 1979.

Poursin, Jean Marie - Mouvements presents et futurs, in Les mouvements de populations et les droits de l'homme.

Reitz Jeffrey G., Hoot Societies and Reception of immigrants, The Center for Comparative Immigration Studies, Steinhard School of Cultural, Education and Human Developments, Immigration Studies, 2007.

Russell, S., International Migration: Implications for the World Bank, working papers, 1994.

Zorlu A. and Hartog J., The Effects of Immigration on Native Earnings, Tinbergen Institute Discussion Paper, 2000. 